\section{In Vitro Colonization of Micropropagated Pieris floribunda by Ericoid Mycorrhizae. II. Effects on Acclimatization and Growth}

\author{
Mark C. Starrett ${ }^{1}$ and Frank A. Blazich ${ }^{2}$ \\ Department of Horticultural Science, North Carolina State University, \\ Raleigh, NC 27695-7609
}

Steven R. Shafer ${ }^{3}$

U.S. Department of Agriculture, Agricultural Research Service, George Washington Carver Center, Beltsville, MD 20705-5140

Larry F. Grand ${ }^{2}$

Department of Plant Pathology, North Carolina State University, Raleigh, NC 27695-7616

Additional index words. Hymenoscyphus ericae, mountain andromeda, micropropagation, mycorrhiza, tissue culture

\begin{abstract}
Inoculation of microshoots of Pieris floribunda (Pursh ex Sims) Benth. and Hook. (mountain andromeda) with isolates of Hymenoscyphus ericae (Read) Korf and Kernan ericoid mycorrhizal fungi stimulated growth during 1 month in vitro. However, no benefits were apparent after 3 months in a greenhouse. Acclimatization of plantlets of $P$. floribunda to greenhouse conditions following in vitro inoculation improved survival (42\% vs. $16 \%$ for controls). The protocol reported herein is similar to procedures utilized currently for micropropagation of various ericaceous species and has potential to improve plantlet survival during acclimatization.
\end{abstract}

Pieris floribunda is an ericaceous, evergreen shrub native to the southeastern United States and has several desirable landscape and cultural characteristics. Unfortunately, supplies are often limited because conventional propagation by sexual means is unreliable and vegetative propagation by stem cuttings results in poor rooting (Dirr and Heuser, 1987). A protocol was developed for successful micropropagation of $P$. floribunda, but greenhouse acclimatization of rooted

\footnotetext{
Received for publication 3 Mar. 1999. Accepted for publication 29 Dec. 1999. This research was funded by the North Carolina Agricultural Research Service (NCARS), Raleigh, NC 27695-7643. Use of trade names in this publication does not imply endorsement by the NCARS or the U.S. Dept. of Agriculture, Agricultural Research Service of products named nor criticism of similar ones not mentioned. The statistical assistance of William H. Swallow and William M. Reece is gratefully acknowledged. Special thanks are due to Vivian Gianinazzi-Pearson for supplying isolate DA of Hymenoscyphus ericae. From a dissertation submitted by M.C.S. in partial fulfillment of the requirements for the $\mathrm{PhD}$ degree. The cost of publishing this paper was defrayed in part by the payment of page charges. Under postal regulations, this paper therefore must be hereby marked advertisement solely to indicate this fact.

${ }^{1}$ Former Graduate Teaching Assistant. Currently: Assistant Professor of Horticulture, Univ. of Vermont, Dept. of Plant and Soil Science, Hills Science Bldg., Burlington, VT 05405-0082. E-mail address: Mark.Starrett@uvm.edu

${ }^{2}$ Professor.

${ }^{3}$ Research Plant Pathologist.
}

microshoots was <38\% (Starrett et al., 1993). Often the greatest losses during micropropagation occur during plantlet acclimatization to greenhouse conditions (Preece and Sutter, 1991). Losses of $20 \%$ to $40 \%$ have been reported for plantlets of Rhododendron L. (rhododendron) during acclimatization (Anderson, 1978). Typically, $10 \%$ of micropropagated plants in the Ericaceae either die or do not attain market standards during acclimatization, causing significant commercial losses (Lemoine et al., 1992). Plantlets produced in vitro also lack mycorrhizal associations and often experience transplant problems when exposed to the natural environment (Ravolanirina et al., 1988). In vitro inoculation with an arbuscular mycorrhizal fungus reduced losses during acclimatization of micropropagated plants of Persea americana Mill. (avocado) (Vidal et al., 1992). Unfortunately, inoculation in vitro with ericoid mycorrhizal fungi does not always improve acclimatization of ericaceous species.

Plantlet survival and subsequent root growth of rooted microcuttings of Rhododendron minus var. chapmanii (A. Gray) Duncan \& Pullen [syn. Rhododendron chapmanii A. Gray (Chapman's rhododendron)] were improved after ex vitro inoculation with Hymenoscyphus ericae (Read) Korf and Kernan [syn. Pezizella ericae (Read)] (Barnes and Johnson, 1986). Inoculation with isolates of $\mathrm{H}$. ericae of seedlings of Vaccinium corymbosum L. (highbush blueberry) (Starrett et al., 1995) and Calluna vulgaris (L.) Hull (heather) (Berta and Gianinazzi-Pearson,
1986), increased growth when plants were cultured in vitro. In contrast, growth was not stimulated by ex vitro inoculation of plantlets of Vaccinium angustifolium Ait. [lowbush blueberry, (Smagula and Litten, 1989)] with $H$. ericae. Similarly, no positive effects were noted following in vitro inoculation of micropropagated shoots of $V$. corymbosum with ericoid mycorrhizal fungi (Lareau, 1985).

There are no published reports on the influence of in vitro inoculation with ericoid mycorrhizae during micropropagation of $P$. floribunda and subsequent evaluation of plant growth ex vitro. Therefore, the objective of this study was to determine the effects of selected ericoid mycorrhizae on ex vitro survival, acclimatization, and subsequent growth of micropropagated plantlets of $P$. floribunda.

\section{Materials and Methods}

On 30 Dec. 1995, 249 flat-bottomed glass shell vials $\left[95 \times 25-\mathrm{mm} \mathrm{Kimble}{ }^{\mathrm{TM}}\right.$ opticlear $^{\circledR}$ (Kimble Glass, Toledo, Ohio)] were prepared with $10 \mathrm{~mL}$ of a mixture of 1 steam-pasteurized, sifted peat : 1 fine vermiculite $(\mathrm{v} / \mathrm{v})$ medium moistened with $5 \mathrm{~mL}$ liquid Woody Plant Medium [WPM (Lloyd and McCown, 1980)] with $200 \mathrm{mg} \cdot \mathrm{L}^{-1} \mathrm{NaH}_{2} \mathrm{PO}_{4}, 80 \mathrm{mg} \cdot \mathrm{L}^{-1}$ adenine hemisulfate, and $5 \mathrm{~g} \cdot \mathrm{L}^{-1}$ sucrose. The $\mathrm{pH}$ was adjusted to 5.2 with $1 \mathrm{~N} \mathrm{KOH}$ prior to placement in the vials. Vials were covered with 25-mm Magenta 2-way caps (Magenta Corp., Chicago), autoclaved for $15 \mathrm{~min}$ at $121^{\circ} \mathrm{C}$, and allowed to cool overnight.

On 1 Jan. 1996, hyphae of ericoid mycorrhizal fungi were transferred aseptically to vials containing the cooled peat : vermiculite medium. Wefts of hyphae $\approx 3 \mathrm{~mm}^{2}$ growing actively on the surface of 1-month-old malt agar cultures of isolate $\mathrm{HE}[=H$. ericae (ATCC \#32985) American Type Culture Collection, Rockville, Md.] and of isolate DA [= isolate A, a putative isolate of $H$. ericae (Lemoine et al., 1992)] were transferred to 83 vials each. A third set of 83 vials remained noninoculated (controls). Vials were recapped and sealed with Parafilm ${ }^{\circledR}$ "M" (American National Can, Greenwich, Conn.). Cultures were placed in a controlled-environment chamber maintained at $23 \pm 1{ }^{\circ} \mathrm{C}$ with a 16 -h photoperiod provided by two cool-white fluorescent lamps suspended $20 \mathrm{~cm}$ above the tops of the vials. Lamps provided a photosynthetic photon flux $[P P F$ $(400-700 \mathrm{~nm})]$ of $\approx 68 \mu \mathrm{mol} \cdot \mathrm{m}^{-2} \cdot \mathrm{s}^{-1}$ as measured at the tops of the vials. These and all other light measurements were recorded with a LI-COR LI-185A quantum/radiometer/ photometer (LI-COR, Lincoln, Nebr.).

On 21 Jan. 1996, five unbranched microshoots of $P$. floribunda $2.5 \mathrm{~cm}$ in length were selected from cultures started on 10 July 1993 (Starrett et al., 2001). Microshoots were placed vertically to a depth of $1 \mathrm{~cm}$ in each of 60 small jars $($ vol. $=140 \mathrm{~mL})$. Each jar contained $30 \mathrm{~mL}$ WPM solidified with $0.8 \%$ TC agar (JRH Biosciences, Lenexa, Kans.), with $200 \mathrm{mg} \cdot \mathrm{L}^{-1} \mathrm{NaH}_{2} \mathrm{PO}_{4}, 80 \mathrm{mg} \cdot \mathrm{L}^{-1}$ adenine hemisulfate, $20 \mathrm{~g} \cdot \mathrm{L}^{-1}$ sucrose, and $62.2 \mu \mathrm{M}$ of the potassium (K) salt of $1 H$-indole-3-butyric acid (K-IBA). This medium was adjusted to $\mathrm{pH} 5.2$ 
with $1 \mathrm{~N} \mathrm{KOH}$ prior to placement in the jars. Cultures were capped with Magenta B-caps (Magenta Corp.), sealed with Parafilm ${ }^{\circledR}$, and maintained at $23 \pm 1{ }^{\circ} \mathrm{C}$ under a 16 -h photoperiod provided by two cool-white fluorescent power groove tubes (GE model F48PG17W; GE Lighting, Cleveland) and two, 25-W, softwhite incandescent bulbs suspended $60 \mathrm{~cm}$ above the tops of the jars. Tubes and bulbs provided a $P P F$ of $\approx 33 \mu \mathrm{mol} \cdot \mathrm{m}^{-2} \cdot \mathrm{s}^{-1}$ at the tops of the jars.

After $10 \mathrm{~d}$ on this medium, microshoots with visible root initials were transferred to the vials previously inoculated with ericoid mycorrhizal fungi and to control vials. Shoots were inserted to a depth of $1 \mathrm{~cm}$ (one shoot per vial). Cultures were maintained at $23 \pm 1{ }^{\circ} \mathrm{C}$ under a $16-\mathrm{h}$ photoperiod provided by four, cool-white fluorescent tubes suspended $12 \mathrm{~cm}$ above the tops of the vials $(P P F \approx 116$ $\left.\mu \mathrm{mol} \cdot \mathrm{m}^{-2} \cdot \mathrm{s}^{-1}\right)$.

After 1 month, data were recorded for total shoot length (main shoot+lateral shoots), branch number, and leaf number. After evaluation, Parafilm ${ }^{\circledR}$ was removed from the vials, and caps were loosened to reduce humidity and to begin acclimatization of the plantlets. The following day, plantlets were transferred to styrofoam cups $(7.5 \mathrm{~cm}$ diameter, vol. $=225 \mathrm{~mL})$ containing a steam-pasteurized, pine bark medium that had been sifted through a $0.6-\mathrm{mm}$ mesh sieve. Prior to transfer of plantlets, holes were made in the base of each cup for drainage. A Spoonula ${ }^{\mathrm{TM}}$ lab-spoon (Fisher Scientific, Pittsburgh) was used to transfer plantlets and all the medium from vials to cups. Plantlets were misted immediately with deionized water. Cups containing plantlets inoculated with the same fungus or those that were noninoculated were grouped on racks (nine cups per rack).

Racks were placed on carts, three racks per cart (one rack each: noninoculated, inoculated with isolate $\mathrm{HE}$, and inoculated with isolate DA), for a total of five carts. Individual racks were separated by clear, plexiglass partitions to prevent cross-contamination. Carts were placed in a glass greenhouse at the Southeastern Plant Environment Laboratory (Phytotron). The greenhouse was maintained at 9-h days/ 15 -h nights of $22 / 18^{\circ} \mathrm{C}$. Plants were subjected to long-day conditions by daily interruption of the dark period from 2300 to $0200 \mathrm{HR}$ with $\approx 11-12 \mu \mathrm{mol} \cdot \mathrm{m}^{-2} \cdot \mathrm{s}^{-1}$ from incandescent lamps (Downs and Thomas, 1991). Tops and sides of carts were covered with three layers of white cotton gauze suspended $73 \mathrm{~cm}$ over the racks, which provided $\approx 70 \%$ reduction of ambient irradiance $\left(\approx 500-600 \mu \mathrm{mol} \cdot \mathrm{m}^{-2} \cdot \mathrm{s}^{-1}\right)$ as measured at solar noon on a clear day at onset of placement of carts in the Phytotron. In addition, upper portions of carts were wrapped with clear plastic along the sides from shelf level ( $77 \mathrm{~cm}$ above floor level) to the top of the gauze ( $150 \mathrm{~cm}$ above floor level). Air movement around racks was maintained through the cart shelves, which were open mesh, and the gauze shade cloth.

Plantlets on carts were misted by deflectiontype mist nozzles suspended $50 \mathrm{~cm}$ above cups and were fertilized daily with standard Phytotron nutrient solution (Downs and Thomas,
1991). For the first $3 \mathrm{~d}$, plantlets were misted daily with deionized water every $30 \mathrm{~min}$ for 15 $\mathrm{s}$. The following $4 \mathrm{~d}$, mist frequency was maintained at 30-min intervals during daylight $(9 \mathrm{~h})$ but was reduced to $15 \mathrm{~s}$ every hour during the night (15 h). Mist frequency was reduced over time as follows: week $2=$ mist every hour (daylight), every $2 \mathrm{~h}$ (night); week $3=$ mist every $2 \mathrm{~h}$ (daylight), every $4 \mathrm{~h}$ (night); week 4 $=$ mist every $4 \mathrm{~h}$ (daylight), off (night). Plants were not misted after week 4 . Thereafter, plantlets were watered once daily with Phytotron nutrient solution. Irradiance was increased to $40 \%$ of ambient after 1 month and increased to $50 \%$ of ambient after an additional month by removal of cotton gauze layers from carts.

The study was terminated 3 months after placement of plantlets in the Phytotron. Plants were harvested and divided into leaves, stems, and roots. Total leaf area and shoot length were measured with a Monochrome AgVision Root and Leaf Analysis System (Decagon Devices, Pullman, Wash.). Leaves were counted and roots and shoots were dried at $70{ }^{\circ} \mathrm{C}$ for $48 \mathrm{~h}$ and weighed. Prior to drying, $50 \mathrm{mg}$ (fresh weight) of each root system was removed to evaluate mycorrhizal colonization. Root subsamples were selected from the same region on each root system, proximal to the base of the shoot. Roots were cleared and stained using a protocol adapted from Brundrett et al. (1984) and examined by bright field microscopy. To quantify root colonization, individual roots were examined for the presence of infected cortical cells. Any root with at least one infected cell was classified as "colonized." Intensity of colonization was determined by counting the number of colonized cortical cells at $\times 400$ magnification using light microscopy $(\approx 25-30$ cells per observation, four observations per subsample).

The experiment was conducted four times, and each experiment (run) was considered a replicate in a randomized complete-block design (RCBD) with treatments in a nested factorial. An experimental unit consisted of one rack (average of nine cups per rack). Because of high plantlet mortality, averages per rack were calculated based on values from living plants only. GLM and LSMEANS were used for statistical analysis (SAS Inst., Cary, N.C., 1990).

The methodology reported herein can be integrated into a micropropagation protocol developed for Rhododendron sp. (Anderson, 1978). The difference, however, between the present study and the protocol of Anderson (1978), is the addition of ericoid mycorrhizal fungi to the medium during in vitro rooting. Time spent under mist in the Phytotron was similar to that used for acclimatization of micropropagated plantlets of Rhododendron sp. (Anderson, 1978). Unfortunately, Pieris requires an additional root initiation phase that is not necessary for Rhododendron (Pennell, 1990). This extra step to induce rooting was incorporated into the micropropagation protocol developed for $P$. floribunda (Starrett et al., 1993). The time at which plantlets of $P$. floribunda grown in the present study were evaluated for initial growth and development (3 months) is the average time when greenhouse- grown plantlets of Rhododendron are transplanted to larger pots (Anderson, 1978).

\section{Results and Discussion}

Prior to placement of plantlets in the Phytotron, effects of mycorrhizal inoculation on shoot length, branch number, and leaf number were evaluated. After incubation for 1 month, in vitro inoculation with isolates HE or DA had significantly increased total shoot length, and both branch and leaf number (Table 1).

Inoculation with isolates $\mathrm{HE}$ or DA increased shoot growth of $P$. floribunda (Table 1). This contrasts with the data of Lareau (1985) who found no positive effects on shoot growth of $V$. corymbosum produced and inoculated in vitro with $H$. ericae. Pons et al. (1982) reported an increase in plant size and vigor in seedlings of Vaccinium myrtillus L. (whortleberry) and C. vulgaris following in vitro inoculation with $H$. ericae. Response to inoculation was rapid, and differences between inoculated and noninoculated seedlings were observed within $15 \mathrm{~d}$ (Pons et al., 1982). Shoot growth of seedlings of Vaccinium macrocarpon Ait. (cranberry) was stimulated by in vitro inoculation with H. ericae (Stribley and Read, 1974; Stribley et al., 1975). Shoot length was increased when seedlings of $V$. corymbosum were inoculated in vitro with isolates of $H$. ericae (Starrett et al., 1995). In addition, shoot length, branch number, and leaf number were increased by inoculation of plantlets of $P$. floribunda in vitro with isolates of H. ericae (Starrett et al., 1996).

Inoculation with either fungus significantly increased survival (Table 1). Survival of micropropagated plantlets of $R$. minus var. chapmanii was also improved by inoculation with $H$. ericae; however, the response was dependent on the $\mathrm{pH}$ of the medium (Barnes and Johnson, 1986). Inoculation during rooting increased survival of transplants of the ericaceous plantArctostaphylos uva-ursi (L.) Spreng. (bearberry) (Holden, 1978). Similarly, inoculation with peat that contained ericoid mycorrhizal fungi increased survival of cuttings of $V$. corymbosum, although survival of cuttings inoculated with pure cultures of $H$. ericae was less than that of noninoculated cuttings or those inoculated with mycorrhizal-peat (Powell and Bagyaraj, 1984).

The presence of isolates of $H$. ericae increases root development on cuttings, seedlings, and microcuttings of ericaceous plants (Berta and Gianinazzi-Pearson; 1986; Pons et al., 1982; Starrett et al., 1995, 1996). Although root development was not quantified prior to placement of plantlets in the Phytotron, root initials were present on all microshoots placed in vials containing the peat : vermiculite medium, with or without fungal inoculum. Furthermore, roots were well-developed on microshoots during transfer of plantlets from vials to cups for placement in the Phytotron. Previously, recommendations for acclimatization were to transplant microshoots just after initiation of roots but prior to root elongation, as roots may be damaged or killed during transfer (Conner and Thomas, 1981; Debergh and Maene, 1981). 
Table 1. Influence of in vitro mycorrhizal inoculation on total shoot length, branch number, and leaf number of rooted microshoots of Pieris floribunda after 1 month of in vitro culture and on survival after 3 months of acclimatization in a greenhouse.

\begin{tabular}{lcccc}
\hline Fungal inoculum & Total shoot length $(\mathrm{cm})$ & Branch no. & Leaf no. & Survival (\%) \\
\hline Noninoculated control & $2.4 \mathrm{a}^{\mathrm{z}}$ & $0.3 \mathrm{a}$ & $10 \mathrm{a}$ & $16 \mathrm{a}$ \\
Isolate HE & $3.1 \mathrm{~b}$ & $0.6 \mathrm{~b}$ & $11 \mathrm{~b}$ & $42 \mathrm{~b}$ \\
Isolate DA & $3.2 \mathrm{~b}$ & $0.6 \mathrm{~b}$ & $12 \mathrm{~b}$ & $42 \mathrm{~b}$ \\
\hline
\end{tabular}

${ }^{\mathrm{z}}$ Mean separation within columns by Fisher's protected LSD at $P \leq 0.01$.

${ }^{\mathrm{y}} \mathrm{HE}=$ Hymenoscyphus ericae [(ATCC \#32985) American Type Culture Collection, Rockville, Md.].

${ }^{x} \mathrm{DA}=$ Putative isolate of $H$. ericae from Dijon, France.

Inoculation with mycorrhizal fungi did not affect total shoot length, branch number, leaf number, leaf area, top dry weight (shoots and leaves), or root dry weight (data not shown) during 3 months of growth in the greenhouse. Lack of initial response may be attributed to the constant availability of nutrients provided by daily fertigation with nutrient solution. Limited supplies of readily available nutrients, especially $\mathrm{N}$, are present in typical heathland soils (Read, 1991) or the soils typical of the habitat where $P$. floribunda is native, and inoculation with ericoid mycorrhizae is beneficial only when N is limiting (Stribley and Read, 1974, 1976; Stribley et al., 1975). Ericaceous plants use ammonium as a source of $\mathrm{N}$ (Townsend, 1970). The amount of available $\mathrm{N}$ from ammonium alone in the Phytotron nutrient solution is $14 \mathrm{mg} \cdot \mathrm{L}^{-1}$, which is adequate for plant growth when supplied daily. A constant quantity of ammonium $\mathrm{N}$ from daily fertilization might have obscured growth benefits from inoculation.

Extent of root colonization was significantly greater for plantlets inoculated with DA than with HE. Following inoculation with HE, only $48 \%$ of the root system was colonized, whereas $68 \%$ was colonized after inoculation with DA. Similarly, intensity of colonization of root cortical cells was slightly, but not significantly, greater for DA $(63 \%)$ than for HE $(57 \%)$. Noninoculated controls were not infected.

Root colonization levels in the present study were comparable with those reported for inoculated microshoots of $R$. minus var. chapmanii (Barnes and Johnson, 1986) and V. corymbosum (Powell, 1982). In another study, however, lower levels of colonization ( $4.5 \%$ to $9.0 \%$ ) occurred in roots of micropropagated plantlets of $V$. angustifolium after a period of growth similar to that used in our study (Litten et al., 1992). Low amounts of root colonization by $H$. ericae are also reported for rooted cuttings of $V$. corymbosum $[(5 \%$ to $30 \%)$ (Powell and Bagyaraj, 1984)]. Surveys of $V$. corymbosum in North Carolina revealed only $1 \%$ to $3 \%$ mycorrhizal infection in commercial plantings, with levels up to $85 \%$ found in native populations (Boyer et al., 1982). Thus, the extent of root colonization of ericaceous plants by ericoid mycorrhizal fungi appears to be variable.

The protocol reported herein is similar to procedures utilized currently for micropropagation of various ericaceous species, and thus has potential to improve survival of plantlets during acclimatization. The protocol also provides a means of inoculating plantlets with mycorrhizal fungi that might aid in later field establishment and growth. Microshoots of $P$. floribunda inoculated with isolate HE or DA grew more than did noninoculated microshoots during 1 month in vitro. However, mycorrhizal inoculation did not stimulate root or shoot development of plantlets provided with adequate nutrition during 3 months growth in a greenhouse. Acclimatization of plantlets of $P$. floribunda to greenhouse conditions following in vitro inoculation with ericoid mycorrhizal fungi improved survival $(42 \%)$ over noninoculated plantlets (16\%). However, additional research is warranted to further improve survival.

\section{Literature Cited} rhododendrons. Proc. Intl. Plant Prop. Soc. 28:135-139.

Barnes, L.R. and C.R. Johnson. 1986. Evaluation of ericoid mycorrhizae and media on establishment of micropropagated Rhododendron chapmanii, Gray. J. Environ. Hort. 4:109-111.

Berta, G. and V. Gianinazzi-Pearson. 1986. Influence of mycorrhizal infection on root development in Calluna vulgaris (L.) Hull seedlings, p. 673-676. In: V. Gianinazzi Pearson and S. Gianinazzi (eds.). Physiological and genetical aspects of mycorrhizae. Proc. 1st European Symp. on Mycorrhizae, Dijon, France, 1-5 July 1985

Boyer, E.P. J.R. Ballington, and C.M. Mainland. 1982. Endomycorrhizae of Vaccinium cory mbosum L. in North Carolina. J. Amer. Soc. Hort. Sci. 107:751-754.

Brundrett, M.C., Y. Piché, and R.L. Peterson. 1984. A new method for observing the morphology of vesicular-arbuscular mycorrhizae. Can. J. Bot. 62:2128-2134.

Conner, A.J. and M.B. Thomas. 1981. Re-establishing plantlets from tissue culture: A review. Proc. Intl. Plant Prop. Soc. 31:342-357.

Debergh, P.C. and L.J. Maene. 1981. A scheme for commercial propagation of ornamental plants by tissue culture. Scientia Hort. 14:335-345.

Dirr, M.A. and C.W. Heuser, Jr. 1987. The reference manual of woody plant propagation: From seed to tissue culture. Varsity Press, Athens, Ga.

Downs, R.J. and J.F. Thomas. 1991. Phytotron procedural manual for controlled environment research at the Southeastern Plant Environment Laboratory. North Carolina Agr. Res. Serv. Tech. Bul. 244 (Revised)

Holden, V.L. 1978. The use of mycorrhizae in the propagation of Arctostaphylos uva-ursi. Proc. Intl. Plant Prop. Soc. 28:132-133.

Lareau, M.J. 1985. Rooting and establishment of in vitro blueberry plantlets in the presence of mycorrhizal fungi. Acta Hort. 165:197-201.

Lemoine, M.C., S. Gianinazzi, and V. GianinazziPearson. 1992. Application of endomycorrhizae to commercial production of Rhododendron microplantlets. Agronomie 12:881-885.

Litten, W., J.M. Smagula, and Y. Dalpé. 1992. Growth of micropropagated lowbush blueberry with defined fungi in irradiated peat mix. Can. J. Bot. 70:2202-2206.

Lloyd, G. and B. McCown. 1980. Commerciallyfeasible micropropagation of mountain laurel, Kalmia latifolia, by use of shoot-tip culture. Proc. Intl. Plant Prop. Soc. 30:421-437.
Anderson, W.C. 1978. Rooting of tissue cultured
Pennell, D. 1990. Micropropagation of the Ericaceae. The Plantsman 12:120-125.

Pons, F., V. Gianinazzi-Pearson, and S. Gianinazzi. 1982. Synthèse in vitro des endomycorrhizes éricoïdes et VA: Complément à la micropropagation. Les Colloques de l'I.N.R.A. 13:345-349.

Powell, C.L. 1982. The effect of the ericoid mycorrhizal fungus Pezizella ericae (Read) on the growth and nutrition of seedlings of blueberry (Vaccinium corymbosum L.). J. Amer. Soc. Hort. Sci. 107:1012-1015.

Powell, C.L. and D.J. Bagyaraj. 1984. Effects of mycorrhizal inoculation on the nursery production of blueberry cuttings-A note. N.Z. J. Agr. Res. 27:467-471.

Preece, J.E. and E.G. Sutter. 1991. Acclimatization of micropropagated plants to the greenhouse and field, p. 71-93. In: P.C. Debergh and R.H. Zimmerman (eds.). Micropropagation. Kluwer Academic, Boston.

Ravolanirina, F., V. Gianinazzi-Pearson, and S. Gianinazzi. 1988. Preliminary studies on in vitro endomycorrhizal inoculation of micropropagated tree species of nutritional value, p. 91-101. In: F.S.P. Ng (ed.). Trees and mycorrhiza. Proc. Asian seminar, Kuala Lumpur, 13-17 Apr. 1987. Forest Res. Inst., Kuala Lumpur, Malaysia.

Read, D.J. 1991. Mycorrhizas in ecosystemsNature's response to the "law of the minimum," p. 101-130. In: D.L. Hawksworth (ed.). Frontiers in mycology: Honorary and general lectures from the Fourth International Mycological Congress, Regensburg, Germany, 1990. CAB Intl., Wallingford, Oxon, U.K.

SAS Institute. 1990. SAS/STAT user's guide. vol. 2. SAS Inst., Cary, N.C.

Smagula, J.M. and W. Litten. 1989. Effect of ericoid mycorrhizae isolates on growth and development of lowbush blueberry tissue culture plantlets. Acta Hort. 241:110-114.

Starrett, M.C., F.A. Blazich, J.R. Acedo, and S.L. Warren. 1993. Micropropagation of Pieris floribunda. J. Environ. Hort. 11:191-195.

Starrett, M.C., F.A. Blazich, L.F. Grand, and S.R. Shafer. 1995. Response of seedlings of highbush blueberry to in vitro ericoid mycorrhizal innoculation [sic]. Proc. Southern Nurserymen's Assoc. Res. Conf., 40th Annu. Rpt. p. 266-268.

Starrett, M.C., F.A. Blazich, L.F. Grand, and S.R. Shafer. 1996. Response of microshoots of mountain andromeda to in vitro ericoid mycorrhizal inoculation. Proc. Southern Nurserymen's Assn. Res. Conf., 41st Annu. Rpt. p. 239-242.

Starrett, M.C., F.A. Blazich, L.F. Grand, and S.R. Shafer. 2001. In vitro colonization of micropropagated Pieris floribunda by ericoid mycorrhizae. I. Establishment of mycorrhizae on microshoots. HortScience 36:353-356.

Stribley, D.P. and D.J. Read. 1974. The biology of mycorrhiza in the Ericaceae: IV. The effect of mycorrhizal infection on uptake of $15 \mathrm{~N}$ from labelled soil by Vaccinium macrocarpon Ait. New Phytol. 73:1149-1155.

Stribley, D.P. and D.J. Read. 1976. The biology of mycorrhiza in the Ericaceae: VI. The effects of mycorrhizal infection and concentration of ammonium nitrogen on growth of cranberry (Vaccinium macrocarpon Ait.) in sand culture. New Phytol. 77:63-72.

Stribley, D.P., D.J. Read, and R. Hunt. 1975. The biology of mycorrhiza in the Ericaceae: V. The effects of mycorrhizal infection, soil-type and partial soil-sterilization (by gamma irradiation) on growth of cranberry (Vaccinium macrocarpon Ait.). New Phytol. 75:119-130.

Townsend, L.R. 1970. Effect of form of $\mathrm{N}$ and $\mathrm{pH}$ on nitrate reductase activity in lowbush blueberry leaves and roots. Can. J. Plant Sci. 50:603-605.

Vidal, M.T., C. Azcón-Aguilar, J.M. Barea, and F. Pleigo-Afaro. 1992. Mycorrhizal inoculation enhances growth and development of micropropagated plants of avocado. HortScience 27:785-787. 